DOI: https://doi.org/10.34069/AI/2021.45.09.26

How to Cite:

Amelicheva, L., Martyniuk, O., Pyroha, I., Qaracayev, C., \& Myroshnychenko, V. (2021). Implementation of constitutional human rights and social guarantees of security in the context of digitalization. Amazonia Investiga, 10(45), 265-271. https://doi.org/10.34069/AI/2021.45.09.26

\title{
Implementation of constitutional human rights and social guarantees of security in the context of digitalization
}

\section{Здійснення конституційних прав людини та соціальні гарантії захищеності в умовах цифровізації}

Received: August 12, 2021

Abstract

Consideration of existing and development of new strategies for human rights in the context of globalization is a very significant topic, as careless management of technological change can pose a serious threat to human dignity, autonomy, privacy, and human existence in general. Purpose: to analyze the level of constitutional human rights in the context of digitalization, to consider the positive and negative impact of technological advances on private life, to explore ways to protect fundamental human rights in the context of globalization. The following methods of scientific cognition are used: comparison, historical, systematic approach to research, method of analysis, and synthesis. As a result of the conducted research, the scientific idea of the importance of observance of constitutional human rights in the conditions of digitalization is formed. In addition, the study examines the positive and negative impact of technological
Accepted: September 30, 2021

Written by:

Liliia Amelicheva ${ }^{103}$

https://orcid.org/0000-0003-0526-5393

Oleksii Martyniuk ${ }^{104}$

https://orcid.org/0000-0001-9160-3525

Ihor Pyroha ${ }^{105}$

https://orcid.org/0000-0002-2798-7795

Ceyhun Qaracayev ${ }^{106}$

https://orcid.org/0000-0002-5222-9224

Volodymyr Myroshnychenko ${ }^{107}$

https://orcid.org/0000-0002-2281-1299

\section{Анотація}

Розгляд існуючих та розробка нових стратегій відносно дотримання прав людини в умовах глобальної цифровізації $\epsilon$ дуже актуальною темою, так як необережне управління технологічними змінами може стати серйозною загрозою для людської гідності, автономії, приватного життя та існування людини в цілому. Мета роботи: проаналізувати рівень дотримання конституційних прав людини в умовах цифровізації, розглянути позитивний та негативний вплив технологічних досягнень на приватне життя людини, дослідити шляхи захисту основоположних прав людини в умовах глобальної цифровізації. В роботі використано такі методи наукового пізнання: порівняння, історичний, системний підхід до дослідження, метод аналізу та синтезу. В результаті проведеного дослідження сформовано наукове представлення про важливість дотримання конституційних прав людини в умовах

\footnotetext{
${ }^{103}$ Doctor of Law, Associate Professor, Professor of the Department of Civil Law and Procedure, Vasyl Stus Donetsk National University, Ukraine.

${ }^{104}$ Candidate of Law, Associate Professor of the Department of Constitutional, International and Criminal Law Vasyl Stus Donetsk National University, Ukraine.

${ }^{105}$ Doctor of Law, Associate Professor, Professor of the Department of Constitutional Law and Comparative Law, Uzhorod National University, Ukraine.

${ }^{106}$ Doctor of Law, Professor of the Department of Constitutional Law, Baku State University, Judge of the Constitutional Court of the Republic of Azerbaijan.

${ }^{107} \mathrm{PhD}$ in Pedagogical Sciences, Associate Professor, Department of Legal Courses, Berdyansk State Pedagogical University, Berdyansk, Ukraine.
} 
advances on private life, explore ways to protect fundamental human rights in the context of globalization and identifies mechanisms for using digitization in public administration, analyzes the legal regulation of informatization is interpreted and effective ways of solving the existing problems of ensuring rights and guarantees are proposed.

Keywords: constitutional human rights, digitization, privacy, databases. цифровізації. Крім того в процесі дослідження розглянуто позитивний та негативний вплив технологічних досягнень на приватне життя людини, дослідити шляхи захисту основоположних прав людини в умовах глобальної цифровізації та визначено механізми використання цифровізації при здійсненні державного управління, проаналізовано правове регулювання інформатизації та запропоновано ефективні способи вирішення існуючих проблем щодо забезпечення прав та гарантій.

Ключові слова: конституційні права людини, цифровізація, приватне життя, бази даних.

\section{Introduction}

Digitization is not only a source of opportunities; digitalization creates many ethical and legal risks and problems. Digital technologies that use large amounts of personal data pose a threat to everyone's right to privacy. Digitalization as a phenomenon of globalization is rapidly penetrating all spheres of human existence: economics, public administration, health care, education, legal sphere, agriculture, culture, religion, etc. The digital economy creates online markets, online exchange, and payment through online banks, the introduction of online services in public administration reduces bureaucracy and increases the speed of administrative services, digitalization of health care allows to detect of diseases at an early stage and prevent epidemics, digitalization education provides its accessibility and personalized approach, in the legal field digital technologies are able to create robots that are deprived of discretionary powers, and thus reduces the number of corrupt practices, the creation of "smart farms", "smart greenhouses" increases agricultural productivity, etc.

In September 2015, the historic United Nations summit adopted the 2030 Agenda for Sustainable Development. This document reflects 17 goals in the field of sustainable human development. UN members recognize that information and digital technologies are integral tools for achieving goals. However, the rapid development of digital technologies not only opens up opportunities but also creates risks, including ethical ones. Digitization undoubtedly increases the ability to communicate with public authorities, promotes speed, objectivity, and the absence of corruption in obtaining public services, but the state receives a large amount of personal information, and the government has the opportunity to increase control and management of privacy man.
This jeopardizes the existence of free and fair elections, reduces freedom of expression, freedom of information, freedom of thought, and belief. There are suggestions that similar phenomena have emerged in the US presidential election, the Brexit referendum, and polls in Brazil and Kenya. Surgical treatment, early detection of diseases, prediction of future diseases, storage of medical histories in digital form, which increases the efficiency of storage of this information, but the risk is a violation of the confidentiality of health data, disclosure, and tracking of devices that monitor health. Increased productivity through digitalization, new sources of employment and income, new markets and opportunities, and the risks in this area - are the full automation of industrial processes, the demise of certain specialties, reducing employment.

Most of the fundamental international instruments on fundamental human and civil rights were adopted in the last century, and global digitization has begun today. In this regard, it is necessary to consider the development and forecasting of the consequences of digitalization, the study of ethical and legal issues arising from the fact that the international community, states, commercial organizations have a large database of personal data, it is essential to analyze existing regulations. legal framework and development of new strategies in the field of protection of constitutional human rights in the context of total digitalization. In the same way, the purpose of the paper, to analyze the level of constitutional human rights in the context of digitalization, to consider the positive and negative impact of technological advances on private life, to explore ways to protect fundamental human rights in the context of globalization. The subject of the study 


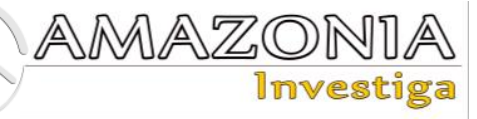

is the implementation of constitutional human rights and social guarantees of protection in the context of digitalization.

The subject of the study is the implementation of constitutional human rights and social guarantees of protection in the context of digitalization.

\section{Theoretical Framework or Literature Review}

Some scientific articles and monographs were analyzed to comprehensively study the topic of the implementation of constitutional human rights and social guarantees in the context of digitalization.

Some works by the following scientists are devoted to the study of protection of rights in the development of digital technologies: Androschuk (2019), Bochkov (2019), Golovko and Dubenets (2020), Gracheva, and Cheremisinova (2018), Egorov and Griga (2019), Kolesnikov (2012), Melnyk (2018), Lopushyntskyi (2018), Lutsky (2013), Petrenko and Mashkovskaya (2020), Ryabokon (2018), and Shakhrai (2020).

The definition of the essence of digitalization is examined in the articles of Petrenko and Mashkovskaya (2020), Lopushyntskyi (2018), Golovko and Dubenets (2020). Thus, the definition of digitalization is reduced to the use of digital technologies in most spheres of public life.

Androschuk (2019) interpreted the case on the right to forgetting, which was won by Google, and drew attention to the peculiarities of the protection of rights on the Internet in the digital age.

Besides, Bochkov (2019) drew attention to the transformation of state institutions in the age of digital reality. Further, Gracheva and Cheremisinova (2018) paid more attention to the constitutional provision of digital rights.

Moreover, Egorov and Griqa (2019) conducted a comparative analysis of the availability of digitalization indicators in Ukraine and other EU Eastern Partnership countries.

Ryabokon (2018) analyzed in detail the state information policy of the formation of the information society, paying attention to foreign experience. In particular, the author notes that the modern state is a catalyst for change in the interests of society and man. It is the state that fights against monopoly and controls the concentration of property in the media and telecommunications business; legally and technologically ensures the rights to access information and information resources for citizens, as well as the protection of personal data; guarantees freedom of speech regardless of the environment of information dissemination; implements measures for the development of multinational culture, opposes the information and cultural expansion of other countries, conducts information policy; carries out purposeful use of information and telecommunication technologies for expansion of dialogue of the power and citizens. One of the conditions for the effective implementation by the state of these areas of state information policy is the development and adoption of relevant strategic documents. The Ministry of Information Policy, established in 2015, was tasked with developing the Information Policy Strategy of Ukraine and the Concept of Information Security of Ukraine, but these tasks have not yet been implemented. In addition, the author noted that the priority tasks of the state in the field of information policy are to ensure the constitutional right to receive, use, disseminate and store information, to freely express their views based on the most effective application for scientific, technical, cultural, social development of those opportunities that provide the latest means of information exchange, production, and promotion at the global level of their information product. The development of the information society in Ukraine is possible only based on a comprehensive approach that contains a strategic vision of informatization of society and is coordinated by the existing socio-economic, political, and cultural priorities of the state and international practice.

The fraudster, in his work "Digital Constitution", investigated the fate of the main rights and freedoms of the individual in the total information society (Shakhrai, 2020).

The study of international experience in the implementation of information technology in the legal system became possible through the analysis of the digitalization process in countries such as Great Britain, France, Germany, Italy, Georgia, Greece, and Estonia.

The following works are devoted to this area: "State policy in the field of information society development in France: prospects for Ukraine" by Melnyk (2018), "Selected decisions of the Federal Constitutional Court of Germany" by Schwabe, and Geisler. 
In addition, normative documents regulating digital rights and mechanisms of public administration with the use of information technologies were used in this direction (Ukrinform, 2021; European Court of Human Rights, 2012; Committee of Ministers, 2005; Human Rights Council, 2018; The EDRi papers, 2021). In particular, the United Nations EGovernment Survey 2018 (UN study on the level of e-government development in different countries), the Constitution of Greece, Georgia, Germany, France, Italy (consolidation of digital rights), etc.

Therefore, we can conclude that the issue of digitalization in the context of human rights has been studied by many scholars, but the implementation of constitutional human rights and social guarantees in the context of digitalization has not been studied comprehensively, so there is a need to analyze this topic in more detail.

\section{Methodology}

During the study of the implementation of constitutional human rights and social guarantees of security in the context of digitalization, a number of methods were used: comparison, historical, systematic approach to research, method of analysis, and synthesis.

Thus, the historical method has become a way to reveal a retrospective of the development of digital technologies in Ukraine and the world. Using the historical method, it is investigated in which historical periods the main acts regulating the provision of individual rights were established, including in the context of digitalization.

The comparative method made it possible to compare foreign experience in the implementation of digitalization and highlight its positive features, which are considered appropriate to use in building a domestic system of digital services and protection of rights.

The method of analysis was useful for the study of digitalization, gradually dividing the study of the theoretical part of the object and the practical, which consists in the analysis of international and Ukrainian experience in the use of information technology. Analytical assessment of the processes of implementation of information technologies makes it possible to identify patterns, according to which it becomes possible to identify specific features of digitalization as a mechanism for effective public administration.
In the future, it was logical to use the method of synthesis, i.e. the location of the analyzed parts alone, grouping by the similarity of features, or building a hierarchical system. Analysis and synthesis act as fruitful methods of cognition only when applied simultaneously. The method of synthesis allowed to gather the studied theoretical and practical aspects into a single whole in order to find the most effective mechanisms for the introduction of digitalization.

Using the system method, the object of study is considered as a set of interconnected elements that have a common goal. It is crucial that the properties of the object as a whole system are determined not only and not so much by summing up the qualities of its elements, but by the properties of its structure, special systemforming, integrative connections of the object.

\section{Results and Discussion}

Human and civil rights and freedoms are the most important social values and the main object of constitutional and legal relations. Their implementation, use, and compliance depend on the level of protection and security. That is why the major element of the constitutional-legal status of the person and the citizen is guarantees of these rights and freedoms.

Digital personal rights, digital selfdetermination, databases, the right to the Internet, digital services, etc. become an integral part of human life. These circumstances are a prerequisite for the formation of a separate legal institution - the Institute of Digital Human Rights.

Digital rights are a relatively new legal category, and therefore their list, definition, and the need for separation are controversial in the scientific legal environment. Thus, there is an opinion that the concept of "digital rights" should not be considered as a separate group of human rights, but as a conditional category that covers the implementation and guarantees of fundamental human rights on the Internet, including freedom of expression and online privacy. Given the huge role that the Internet plays in modern life, the separation of this category helps to better systematize and study the needs of human rights in the online environment, some guarantees of which are now scattered in the recommendations, resolutions, and other acts of international institutions. Other researchers consider digital rights to be derived from informational rights, but not identical, and emphasize the need to 


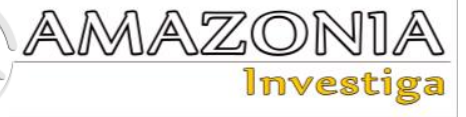

separate them into a separate group. Digital rights are also understood as the rights of citizens to access, use, create and publish digital works, the right to free access to the Internet (other communication networks) using computers and other electronic devices (Bochkov, 2019).

Despite the controversial nature of the problem, it should be recognized that the development of digital technologies does affect the development of constitutional human rights and their further legal regulation and protection.

The UN has repeatedly considered the issue of digital rights. In particular, it was declared that the right to the Internet is an inalienable human right that must be ensured at all levels, and emphasis was placed on its crucial role in the development of society, and the rights that a person has in the offline environment are protected in the online environment. The UN calls on all states to respect and protect the right to privacy, including in the context of digital communication.

However, despite loud calls and proposals for a settlement, the public and legislative consciousness are currently undergoing a process of a qualitatively renewed understanding of the content of human rights, which necessitates the development of a system of constitutional guarantees and mechanisms for human rights protection in the context of digital transformation.

Analysis of the regulatory experience of foreign countries allows us to identify two ways of domestic regulation of digital rights (Table 1):

Table 1.

The ways of domestic regulation of digital rights. Own authorship.

\begin{tabular}{ll}
\hline Path 1 & Path 2 \\
\hline & the digitization of constitutional rights, in which \\
The constitutionalization of digital rights, which & $\begin{array}{l}\text { the rights enshrined in the constitution are } \\
\text { changes the text of the constitution in order to } \\
\text { updated or regulated based on decisions of } \\
\text { level }\end{array}$ \\
& $\begin{array}{l}\text { constitutional jurisdiction, the case-law of the } \\
\text { European Court of Human Rights, or in relevant } \\
\text { legislation }\end{array}$ \\
\hline
\end{tabular}

The first way is appropriate for those countries that develop and adopt constitutions in the twentieth century, but there are examples of changes to already adopted constitutions. For example, the Constitution of Greece in 2001 was supplemented by Art. 5A, where Part 2 enshrines the right of all persons to participate in the information society and to facilitate access to information transmitted in electronic form. Digital rights are formulated in more detail in the Constitution of Georgia (Law No. 2071, 1995), which is 2018, in the process of constitutional reform, made appropriate changes and defined the right of everyone to access and use the Internet (paragraph 4 of Article 17).

The second way is relevant for countries, that recognize the need for normative consolidation and a renewed understanding of fundamental constitutional rights in the digital age but are not yet ready to change the Constitution.

Quite often, they use either body of constitutional jurisdiction, which, without changing the "body of the constitution", interpret certain constitutional norms in the light of digital reality, or adopt certain laws governing digital rights.
An example of such a transformation is Germany, where the regulation of digital rights (for information self-determination, for ensuring the integrity and confidentiality of information technology systems (IT-law), for the secrecy of correspondence, mail, and telecommunications, for the inviolability of housing) mainly has a socalled "judicial origin" because in the absence of normative enshrinement in the relevant legislation is governed by decisions of the Federal Constitutional Court of Germany. That is, normalization occurs as needed in cases of legal conflict. However, the essence of these rights does not change but is only interpreted through the prism of digital transformation. In this context, the experience of France is impressive, which, carrying out a gradual interpretation of digital rights by a body of constitutional jurisdiction, realized the need to adopt a codified legal act.

The digital transformation presupposes the need to receive appropriate constitutional standards in ensuring and realizing human rights, without which the further development of constitutionalism in the conditions of digital transformation is impossible. One of them is the 
need for regulatory definition and regulation of the right to access the Internet.

Ukraine is moving towards defining the right to access the Internet at the level of relevant legislation, which, on the one hand, allows to comply with all ratified conventions and recommendations of international organizations, and on the other - not to amend the Constitution.

In the process of digital transformation, the list of constitutional human rights is gradually expanding and receives a qualitative update of the semantic interpretation.

Increasingly, we have to meet the right to data portability and the right to be forgotten. This is the so-called right of the data subject to object to the further processing of the data and the obligation of the data controller to delete the information immediately after it ceases to be necessary for processing.

For example, the right to forgetting is treated as a human right that allows a person to demand, under certain conditions, the removal of his or her data from public access through search engines i.e. links to data that he or she believes may harm him or her. This applies to outdated, inappropriate, incomplete, inaccurate, or redundant data or information, the legal grounds for storage of which have disappeared over time.

Moreover, the right to be forgotten is a dispute between Mario Costeja Gonzalez's complaint against Google Inc and La Vanguardia Ediciones SL (Judgment No. C-131/12, 2014), which was heard by the EU's highest court, the European Court of Justice, which ruled on 13 May 2014, that European law gives EU citizens the right to apply to any search engine with a request to remove links relating to personal information about the applicant. Inadequate and outdated data, as well as those that are excessive in relation to the purposes for which they were posted on the Internet, are subject to deletion. This decision has set a precedent that provides a basis for revising the list of constitutional human rights and their expansion and provides legal instruments for the protection of human rights and freedoms, as well as a real guarantee of protection of such rights.

But even though the rights are enshrined in the laws of many states, there is a need to regulate legislative guarantees. This circumstance indicates the need to ensure and implement digital human rights. It is necessary to develop a concept of digital duties and responsibilities for the violation of these rights.
Thus, the exercise of constitutional human rights and social guarantees of protection in the context of digitalization require a comprehensive approach both by the state and by the consumer of such rights and by society as a whole.

\section{Conclusions}

As a result of the study of the implementation of constitutional human rights and social guarantees of protection in the context of digitalization, the following was established.

1. In the process of legal digitalization an essential role is played by the normative consolidation of digital rights, which allows regulating the relations that arise in the process of human interaction during the use of information technology and use effective mechanisms to protect such rights.

2. Analysis of international experience confirms that depending on the level of interest of a particular country in its integration into the world communication system depends on the direction of digital policy of the state and ways to reform the state in this context.

3. Digital transformation presupposes the need to receive appropriate constitutional standards in the field of ensuring and realizing human rights, without which the further development of constitutionalism in the conditions of digital transformation is impossible. One of them is the need to normatively define and regulate the right to access the Internet.

Thus, based on the analysis of international experience in the field of digitalization of law, we can conclude that there is a gradual "blurring of information borders" and improving the system of settlement of relations arising from the use of digital rights (France, Italy, Germany, Greece, Georgia). For effective public administration, digital technologies are an effective tool that requires applied research and development.

Regarding further scientific research, it is essential to examine the draft laws and the work of the committees of the Verkhovna Rada of Ukraine on the consolidation of digital rights in legislation.

\section{Bibliographic references}

Androschuk, G. (2019). Court of Justice: Google has won the dispute over the right to forget. Legal Gazette. Recovered from https://yur- 


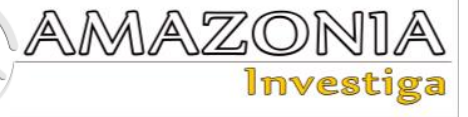

gazeta.com/publications/practice/zahistintelektualnoyi-vlasnosti-avtorske-pravo/sudes-google-vigrav-spir-shchodo-prava-nazabuttya.html

Arbeláez-Campillo, D., Tatsiy, V., Rojas-Bahamón, M., \& Danilyan, O. (2020). Contributions of critical thinking as a form of participation and political deliberation. Amazonia Investiga, 9(27), 5-12. https://doi.org/10.34069/AI/2020.27.03.1

Bochkov, A.A. (2019). The modern state in the context of digital reality. Right. Economy. Psychology, 3, 3-9. Recovered from https://rep.vsu.by/handle/123456789/17978

Committee of Ministers. (2005). Declaration CM (2005)56, Declaration of the Committee of Ministers on human rights and the rule of law in the Information Society. Council of Europe. Recovered from https://www.coe.int/t/dgap/goodgovernance/Ac tivities/Public_participation_internet_governan ce/Declaration-InformationSociety/011_DeclarationFinal\%20text_en.asp

Egorov, I. Yu., \& Griga, V. Yu. (2019). A Porous Analysis of the Evidence of Indicators of Digitalization in Ukraine and the Other Territories of the EU Shared Partnership. Statistics of Ukraine, 3, 56-62. Recovered from http://nbuv.gov.ua/UJRN/su_2019_3_8

European Court of Human Rights. (2012). Internet: Case-law of the European Court of Human Rights. Recovered from https://www.echr.coe.int/Documents/Research _report_Internet_RUS.pdf

Golovko, O.M., \& Dubenets, A.S. (2020). The role of digitalization of public services in legal relations with a foreign element. Information and law, 2(33), 170-176. Recovered from http://ippi.org.ua/sites/default/files/18_8.pdf

Gracheva, S.A., \& Cheremisinova, M.E. (2018). Issues of constitutional provision of digital rights. MGPU Bulletin, 4(32), 56-70. DOI 10.25688/2076-9113.2018.32.4.06 Recovered from https://vestnik.mgpu.ru/pdf/1565.pdf

Human Rights Council. (2018). 38th session. Agenda item 3. Promotion and protection of all human rights, civil, political, economic, social and cultural rights, including the right to development. Recovered from https://www.ohchr.org/EN/HRBodies/HRC/Re gularSessions/Session38/Pages/38RegularSessi on.aspx

Judgment No. C-131/12, Google Spain v Agencia Española de Protección de Datos (AEPD). Court of Justice of the European Union, Luxembourg, 13 May 2014. Recovered from https://curia.europa.eu/jcms/upload/docs/applic ation/pdf/2014-05/cp140070en.pdf
Kolesnikov, B. (2012). Status and prospects of information society development in Ukraine. Public administration and local selfgovernment, 3(14), 37-45. Recovered from http://www.dridu.dp.ua/vidavnictvo/2012/2012 _03(14)/12kbpisu.pdf

Law No. 2071, The Constitution of Georgia. August 24, 1995. Recovered from https://matsne.gov.ge/ru/document/view/30346? publication=35

Lopushynskyi, I.P. (2018). "Digitalization" as the Basis of Public Administration on the Path of Transforming and Reforming of the Ukrainian Society. Theory and practice of public administration and local self-government, 2, 118. Recovered from http://el-zbirndu.at.ua/2018_2/20.pdf

Lutsky, R.P. (2013). Modern approaches to understanding the essence of positive law from the point of view of leading legal scholars. Rule of law, 16, 48-52. Recovered from http://nbuv.gov.ua/UJRN/Prav_2013_16_8

Melnyk, M. (2018). State policy in the field of information society development in France: prospects for Ukraine. Edition, 4 (11), 48-57. Recovered from http://www.dridu.dp.ua/vidavnictvo/2011/2011 _04(11)/11mmvfpu.pdf

Petrenko, N.O., \& Mashkovskaya, N.V. (2020). Development of the state and law: questions of theory and constitutional practice, 2, 112-119. Recovered from http://pravoisuspilstvo.org.ua/archive/2020/2_2 020/part_1/20.pdf

Ryabokon, O. (2018). State information policy of information society formation: foreign experience. Center for Research of Social Communications NBUV Recovered from http://nbuviap.gov.ua/index.php?option=com content \&view=article \&id=3244:derzhavnainformatsijna-politika-formuvannyainformatsijnogo-suspilstva-zarubizhnijdosvid \& catid $=81 \&$ Itemid $=415$

Shakhrai, S.M. (2020). "Digital" Constitution. The fate of fundamental rights and freedoms of the individual in a total information society. Recovered from https://audit.msu.ru/vshga_news/8448/

The EDRi papers. (2021). The Charter of Digital Rights. Recovered from https://edri.org/wpcontent/uploads/2014/06/EDRi_DigitalRightsC harter_web.pdf

Ukrinform. (2021). Dosvid Estonii can help Ukraine more succumb to the path of digitalization. Recovered from https://www.ukrinform.ua/rubrictechnology/3248455-te-so-jde-na-oboronucifrovizacia-v-estonii-zaosadzue-2-vvppremerka.html 